\title{
PERANAN EKSPLORASI PUSTAKA UNTUK MENINGKATKAN KETRAMPILAN MENULIS PADA SISWA KELAS IV SDN GUNUNG AGUNG
}

\author{
Resmiyati \\ Guru SDN Gunung Agung, resmiyati@gmail.com
}

\begin{tabular}{l} 
INFO ARTIKEL \\
\hline Riwayat Artikel: \\
Diterima: $20-02-2018$ \\
Disetujui: $21-03-2018$ \\
\hline
\end{tabular}

Kata Kunci:

Eksplorasi Pustaka, Kemampuan Menulis

\begin{abstract}
ABSTRAK
Abstrak: Penelitian ini untuk mengungkapkan peran Bagaimana Pendekatan Eksplorasi Pustaka dapat meningkatkan ketrampilan menulis pada siswa kelas IV di SDN Gunung Agung, Kecamatan Pringgarata, Kabupaten Lombok Tengah tahun 2014/2015. Menggunakan pendekatan deskriptif kualitatif jenis penelitia tindakan kelas dua siklus, pengumpulan data dengan metode tes, pustaka, observasi, dan dokumentasi. Diperoleh hasil, yaitu: Kategori A mengalami kenaikan 4\%. Kategori B mengalami kenaikan $35 \%$. Kategori C mengalami kenaikan $10 \%$. Kategori D mengalami penurunan $46 \%$. Kategori E mengalami penurunan 4\%. Kesimpulan bahwa Kegiatan Eksplorasi Pustaka dapat meningkatkan kemampuan menulis dalam Peembelajaran Bahasa Indonesia bagi siswa kelas IV SDN Gunung Agung Tahun 2014/2015.
\end{abstract}

\begin{abstract}
This research is to reveal the role of How Exploration Approach Pustaka can improve writing skills in fourth grade students in Gunung Agung Elementary School, District Pringgarata, Central Lombok regency 2014/2015. Using a qualitative descriptive approach type of second class action research cycle, data collection by test method, library, observation, and documentation. The results obtained, namely: Category $A$ has increased 4\%. Category B increased 35\%. Category C has increased 10\%. Category $D$ has decreased by $46 \%$. Category $E$ has decreased by $4 \%$. Conclusion that Activity Exploration Pustaka can improve writing skill in Indonesian Language Learning for grade 4 student of SDN Gunung Agung Year 2014/2015.
\end{abstract}

\section{A. LATAR BELAKANG}

Ketrampilan menulis siswa berkaitan erat dengan kegiatan membaca. Faktor yang mampu mendorong Minat Baca antara lain : 1) Rasa ingin tahu atas fakta, teori, prinsip, pengetahuan, informasi dan lainnya. 2) Fasilitas yang memadai. 3) Terciptanya situasi yang kondusif . 4) Membaca adalah suatu kebutuhan.

Dalam mengatasi permasalahan ini, penulis ingin menerapkan tentang Eksplorasi Pustaka sebagai wadah pengembangan bidang kebahasaan dan kesastraan. Dengan menggunakan fasilitas perpustakaan yang ada di sekolah, siswa dapat memanfaatkan perpustakaan sebagai sumber belajar, dengan begitu siswa telah melakukan pembelajaran eksplorasi terhadap lingkungannya.

Guru mengalami kendala dalam menyampaikan pembelajaran mengarang(menulis cerita) maupun menulis sinopsis yang sering menjadi bahan untuk lomba. Melihat hasil penulisan siswa dalam bercerita atau membuat sinopsis, sangat banyak siswa yang menulis asal jadi saja, padahal kita sebagai guru telah menyampaikan cara-cara menulis sebuah cerita dengan harapan siswa bisa menulis dengan lebih baik.
Sehingga dalam penelitian ini adalah Bagaimana meningkatkan ketrampilan menulis pada siswa kelas IV di SDN Gunung Agung, Kecamatan Pringgarata, Kabupaten Lombok Tengah Tahun 2014/2015.

\section{B. METODE PENELITIAN}

\section{Subyek Penelitian}

Penelitian ini dilakukan di SDN Gunung Agung pada siswa kelas 4 th. Ajaran 2014-2015. Penelitian tersebut tentang peranan eksplorasi pustaka untuk meningkatkan keterampilan menulis dalam pembelajaran Bahasa Indonesia khususnya maupun pelajaran lainnya.

\section{Rancangan Penelitian}

Prosedur yang digunakan dalam penelitian ini adalah prosedur penelitian tindakan kelas. Penelitian tindakan kelas secara garis besar terdapat empat tahapan yang lazim dilalui, yaitu: (1) perencanaan, (2) pelaksanaan tindakan, (3) pengamatan (observasi), dan (4) refleksi, yang merupakan langkah berurutan dalam satu siklus yang berhubungan dengan siklus berikutnya. 
a. Tahap Perencanaan

1) Membuat rencana pelaksanaan pembelajaran.

2) Menyiapkan LKS dan soal-soal diskusi kelompok.

3) Menyiapkan lembar observasi aktivitas siswa dan guru.

4) Menyusun kisi-kisi soal evaluasi.

5) Menyusun tes hasil belajar dalam bentuk pilihan ganda.

b. Pelaksanaan Tindakan

1) Pendahuluan

2) Mensosialisasikan pada siswa mengenai pembelajaran kooperatif tipe group investigation (GI).

3) Menyampaikan indikator hasil belajar.

4) Guru membagi siswa kedalam kelompok yang setiap kelompok terdiri dari 4-5 orang anggota yang salah satu anggotanya harus menjadi pemimpin/ketua kelompok.

5) Guru memberikan motivasi dan apersepsi yang berkaitan dengan materi yang akan dipelajari.

c. Pengembangan

1) Guru membagi kelas menjadi beberapa kelompok yang heterogen.

2) Guru menjelaskan maksud pembelajaran dan tugas kelompok yang harus dikerjakan.

3) Guru memanggil ketua-ketua kelompok untuk memanggil materi tugas secara kooperatif dalam kelompoknya.

4) Masing-masing kelompok membahas materi tugas secara kooperatif dalam kelompoknya.

5) Setelah selesai, masing-masing kelompok yang diwakili ketua kelompok atau salah satu anggotanya menyampaikan hasil pembahasannya.

6) Kelompok lain dapat memberikan tanggapan terhadap hasil pembahasannya.

7) Guru memberikan penjelasan singkat (klarifikasi) bila terjadi kesalahan konsep dan memberikan kesimpulan.

d. Penerapan

1) Guru melakukan penilaian terhadap hasil kerja siswa.

2) Guru memberikan penguatan terhadap hasil kerja kelompok.

3) Siswa dan guru bersama-sama mengevaluasi (mengomentari, memberi kritik dan saran) terhadap penampilan dan materi laporan masing-masing kelompok.

4) Siswa bertanya pada guru tentang materi yang kurang jelas

5) Pemberian penguatan. e. Penutup

1) Guru bersama siswa membuat rangkuman/simpulan hasil pembelajaran.

2) Guru melakukan tanya jawab sebagai wujud umpan balik materi pembelajaran.

3) Guru menginformasikan materi pembelajaran pada pertemuan selanjutnya.

4) Guru melakukan evaluasi.

5) Siswa dan guru bersama-sama mengambil kesimpulan dari pembelajaran yang telah dilalui.

6) Pemberian Tindak Lanjut.

f. Tahap Observasi dan Evaluasi

Pada tahap ini dilakukan observasi terhadap pelaksanaan tindakan dengan menggunakan lembar observasi, dimana guru dan siswa di observasi tentang pelaksanaan kegiatan belajar mengajar serta aktivitas siswa dalam belajar, apakah pembelajaran kooperatif tipe group investigation (GI) sudah dilaksanakan dengan optimal. Tahap evaluasi dilakukan setelah akhir tiap siklus dengan memberikan tes berbentuk pilihan ganda.

g. Tahap Refleksi

Hasil yang diperoleh pada tahap observasi dan evaluasi dikumpulkan dan dianalisa pada tahap ini. Dari hasil observasi dan evaluasi pada siklus I guru mengidentifikasi kesalahan dan kekurangan, menganalisis penyebab kekurangan dan merefleksi diri untuk melakukan persiapan menyusun tindakan perbaikan untuk melaksananakan siklus II. Tindakan yang sama juga dilakukan untuk siklus II-III dan selanjutnya.

\section{Teknik Pengambilan Data}

1. Sumber data

Sumber data dalam penelitian ini adalah siswa kelas IV SD Gunung Agung Tahun 2014/2015.

2. Jenis-jenis data
a. Data hasil belajar
b. Data hasil observasi aktivitas siswa
c. Data hasil observasi aktivitas guru
d. Data skenario pembelajaran

3. Cara pengambilan data

a. Data hasil belajar yang diperoleh dari hasil evaluasi dengan menggunakan tes pilihan ganda yang telah disiapkan pada akhir siklus.

b. Data tentang aktivitas siswa di dalam kelas diambil dengan menggunakan lembar observasi pada tiap siswa.

c. Indikator perilaku siswa yang diamati pada penelitian ini adalah:
1) Kesiapan siswa dalam menerima pelajaran. 
2) Antusiasme siswa dalam mengikuti pembelajaran kooperatif tipe group investigation (GI).

3) Interaksi siswa dengan guru.

4) Aktivitas siswa dalam kegiatan kelompok.

5) Kerjasama kelompok dalam kegiatan diskusi.

6) Kemampuan siswa dalam menyimpulkan hasil belajar.

\section{Teknik Analisis Data}

a. Data Hasil Belajar

Data tentang hasil belajar siswa dianalisis secara deskriptif kualitatif. Sedangkan kualifikasi prestasi belajar siswa diperoleh dengan pedoman konversi seperti tabel 1 berikut:

TABEL 1

PEDOMAN KONVERSI SKOR HASIL BELAJAR SISWA

\begin{tabular}{|c|c|c|}
\hline NO. & SKOR & KATEGORI \\
\hline 1. & $85-100$ & Sangat Baik \\
\hline 2. & $70-84$ & Baik \\
\hline 3. & $55-69$ & Cukup \\
\hline 4. & $40-54$ & Kurang \\
\hline 5. & $0-39$ & Sangat Kurang \\
\hline
\end{tabular}

Untuk mengetahui adanya peningkatan hasil belajar siswa pada pembelajaran matematika yang dicapai pada tiap siklus, digunakan rumus sebagai berikut:

1) Menentukan rata-rata

$$
\overline{\boldsymbol{X}}=\frac{\text { Jumlah Nilai Siswa }}{\text { Jumlah Siswa Yang Mengikuti Tes }}
$$

2) Menentukan ketuntasan individual

Setiap siswa dalam proses belajar mengajar dikatakan tuntas secara individu terhadap materi pelajaran yang disajikan apabila siswa mampu memperoleh nilai $\geq$ KKM.

3) Menghitung ketuntasan klasikal

$$
K K=\frac{X}{N} x 100 \%
$$

Dengan KK menyatakan ketuntasan klasikal, X menyatakan jumlah siswa yang memperoleh nilai $\geq$ KKM, dan $\mathrm{N}$ menyatakan jumlah siswa sesuai dengan petunjuk teknik penilaian. Kelas dikatakan tuntas secara klasikal terhadap materi pelajaran yang disajikan jika ketuntasan klasikal mencapai $85 \%$. b. Aktivitas Siswa

Aktivitas siswa dapat diketahui melalui observasi terhadap perilaku siswa selama mengikuti pembelajaran dengan lembar observasi terdiri dari 6 indikator, tiap indikator terdiri dari 3 deskriptor. Data aktivitas siswa dianalisis dengan cara berikut:

1) Menentukan skor untuk tiap deskriptor aktivitas siswa. Menentukan rata-rata skor tiap indikator dilakukan dengan cara menjumlahkan semua skor pada tiap deskriptor dari indikator tersebut kemudian dibagi dengan banyaknya deskriptor pada indikator tersebut.

2) Data aktivitas siswa dianalisis secara deskriptif kualitatif dengan menggunakan skor skala 1-5, sehingga diperoleh skor maksimal ideal (SMI) adalah skor maksimalnya 3 dikalikan dengan jumlah item aktivitas siswa yang dinilai.

Kualifikasi belajar siswa ditentukan berdasarkan pedoman konversi seperti pada tabel 2 berikut:

TABEL 2

PEDOMAN KONVERSI PENILAIAN SKALA 15 AKTIVITAS BELAIAR SISWA.

\begin{tabular}{|c|c|}
\hline SKOR & KUALIFIKASI \\
\hline $\mathrm{MI}+1,5 \mathrm{SDI} \leq X$ & Sangat Aktif \\
\hline $\mathrm{MI}+0,5 \mathrm{SDI} \leq X<$ & Aktif \\
$\mathrm{MI}+1,5 \mathrm{SDI}$ & \\
\hline $\mathrm{MI}-0,5 \mathrm{SDI} \leq X<$ & Cukup Aktif \\
$\mathrm{MI}+0,5$ SDI & \\
\hline $\mathrm{MI}-1,5 \mathrm{SDI} \leq X<$ & Kurang Aktif \\
$\mathrm{MI}-0,5$ SDI & \\
\hline$X<\mathrm{MI}-1,5$ SDI & $\begin{array}{c}\text { Sangat Kurang } \\
\text { Aktif }\end{array}$ \\
\hline
\end{tabular}

\section{HASIL DAN PEMBAHASAN}

\section{Hasil Siklus I}

Pada akhir proses belajar mengajar siswa diberi tes formatif I dengan tujuan untuk mengetahui tingkat keberhasilan siswa dalam proses belajar mengajar yang telah dilakukan. Adapun data hasil penelitian pada siklus I adalah sebagai berikut:

TABEL 2

DATA HASIL PROSES KBM SISWA

\begin{tabular}{|c|c|}
\hline NILAI & JUMLAH SISWA \\
\hline $\mathrm{A}=9.0-10$ & 0 \\
\hline $\mathrm{B}=8.0-8.9$ & 1 \\
\hline $\mathrm{C}=7.0-7.9$ & 12 \\
\hline $\mathrm{D}=6.0-6.9$ & 14 \\
\hline $\mathrm{E}<6.0$ & 1 \\
\hline Jumlah Siswa & 28 \\
\hline
\end{tabular}


Pada Siklus I, hasil pembelajaran kurang memuaskan karena masih banyak siswa yang memiliki nilai rata-rata 6,0-6,9, antara lain disebabkan:

a. Anak hanya terpaku pada bacaan cerita yang ada pada bacaan buku pelajaran (tidak ada alternatif pilihan yang lain yang menjadi kesukaan anak).

b. Anak kurang tertarik karena ceritanya membosankan (tidak ditunjang dengan gambar yang menarik)

c. Metode pembelajaran yang berupa pemberian tugas dari guru, kurang begitu menantang, karena dalam pemberian tugas, anak hanya terdoktrin harus mengerjakan tugas tersebut tanpa dapat menyalurkan semua kemampuan bakat dan minatnya dalam membaca dan menulis cerita sederhana.

\section{Siklus II}

TABEL 3

DATA HASIL SIKLUS II

\begin{tabular}{|c|c|}
\hline NILAI & JUMLAH SISWA \\
\hline $\mathrm{A}=9.0-10$ & 1 \\
\hline $\mathrm{B}=8.0-8.9$ & 11 \\
\hline $\mathrm{C}=7.0-7.9$ & 15 \\
\hline $\mathrm{D}=6.0-6.9$ & 1 \\
\hline $\mathrm{E}<6.0$ & 0 \\
\hline Jumlah Siswa & 28 \\
\hline
\end{tabular}

Tabel 4

PERSENTASE PENCAPAIAN TARGET

\begin{tabular}{|c|c|c|c|c|c|c|}
\hline NO & KA & \multicolumn{2}{|c|}{ SIKLUS I } & \multicolumn{2}{|c|}{ SIKLUS II } & $\begin{array}{c}\text { KETERANG } \\
\text { AN } \\
\text { TE } \\
\text { GO } \\
\text { RI }\end{array}$ \\
& & ORG & $\begin{array}{c}\text { PERS } \\
\text { EN }\end{array}$ & ORG & $\begin{array}{c}\text { PERS } \\
\text { EN }\end{array}$ & \\
\hline & & & $0 \%$ & 1 & $4 \%$ & Meningkat \\
\hline 1 & $\mathrm{~A}=$ & 0 & $0 \%$ & 11 & $39 \%$ & Meningkat \\
\hline 2 & $\mathrm{~B}=$ & 1 & $4 \%$ & 11 & $53 \%$ & Meningkat \\
\hline 3 & $\mathrm{C}=$ & 12 & $42 \%$ & 15 & $53 \%$ & Menurun \\
\hline 4 & $\mathrm{D}=$ & 14 & $50 \%$ & 1 & $4 \%$ & Menurun \\
\hline 5 & $\mathrm{E}=$ & 1 & $4 \%$ & 0 & $0 \%$ & \\
\hline
\end{tabular}

Diskripsi hasil persentase:

a. Kategori A mengalami kenaikan jumlah siswa sebanyak 1 orang dan mengalami kenaikan prosentasi sebesar $4 \%$.

b. Kategori B mengalami kenaikan jumlah siswa sebanyak 10 orang dan mengalami kenaikan prosentasi sebesar $35 \%$.

c. Kategori $\mathrm{C}$ mengalami kenaikan jumlah siswa sebanyak 3 orang dan mengalami kenaikan prosentasi sebesar $10 \%$.

d. Kategori D mengalami penurunan jumlah siswa sebanyak 13 orang dan mengalami penurunan prosentasi sebesar $46 \%$. e. Kategori E mengalami penurunan jumlah siswa sebanyak 4 orang dan mengalami penurunan prosentasi sebesar $4 \%$.

Dari data diatas, tampak perkembangan nilai hasil belajar pada kategori A,B,C, meningkat jadi eksplorasi perpustakaan memberikan pengaruh positif dalam peningkatan hasil belajar. Juga pada kategori D dan E, terjadi penurunan jumlah siswa, yang berarti terjadi peningkatan hasil belajar dari kategori D dan E meningkat menjadi kategori A,B atau C.

\section{Deskripsi Temuan}

Namun setelah diadakan Siklus II, dengan memakai kegiatan eksplorasi pustaka, siswa mengalami perubahan peningkatan, terbukti pada kenaikan jumlah siswa yang mendapat nilai rata-rata $9,0-9,9 ; 8,0-8,9 ; 7,0-7,9$ dan penurunan jumlah siswa yang mempunyai nilai rata-rata $6,0-6,9$ dan kurang dari 6,0.

Kegiatan eksplorasi pustaka sangat membantu siswa untuk terjun langsung dengan lingkungannya. Hal-hal yang dapat langsung diperoleh antara lain:

a. Pengalaman tak terlupakan ketika siswa menemukan cerita lalu memahami isi bacaan yang disukainya.

b. Siswa dengan leluasa menikmati bacaan dengan suasana tenang dan santai

c. Siswa dapat menemukan nara sumber lain bila menemukan kesulitan, ini menunjukkan bahwa siswa memiliki rasa ingin tahu yang besar.

Dari beberapa kegiatan yang telah dilakukan oleh guru, ternyata kegiatan pembelajaran dengan metode eksplorasi sangat banyak manfaatnya, baik dilihat dari segi guru maupun siswa.

Dari segi guru, kegiatan eksplorasi pustaka merupakan ide kreatif dan inovatif dalam merencanakan pelaksanaan pembelajaran. Guru hanya berperan sebagai fasilitator dan siswalah yang aktif melakukan kegiatan.

Dari segi siswa, kegiatan eksplorasi pustaka banyak membantu siswa mempelajari karya fiksi maupun non fiiksi, guna mengembangkan dan meningkatkan minat membaca dan menulis. Selain itu suasana kelas tampak lebih aktif karena siswa lebih responsif. Selain itu siswa akan mendapat pengalaman secara langsung dan tidak terlupakan. Minat dan bakat siswa dapat tergali melalui kegiatan eksplorasi yang secara tidak langsung merangsang siswa untuk mempunyai rasa ingin tahu yang besar. Sehingga akan tampak perubahan perkembangan yang sangat mencolok pada diri siswa. 


\section{SIMPULAN DAN SARAN}

Kegiatan Pembelajaran yang dilakukan guru bilamana belum mencapai batas ketuntasan menuntut guru untuk melakukan perbaikan pembelajaran. Hal ini dapat dipastikan ketidakberhasilan tersebut karena kurang optimalnya guru melibatkan instrumen pembelajaran dan kurangnya inovasi dan kreativitas dalam menciptakan suasana pembelajaran yang lebih menyenangkan dan memberi pengalaman baru kepada siswa.

Secara umum dapat ditarik kesimpulan sebagai berikut :

1. Keberhasilan siswa dapat ditingkatkan karena guru dapat merancang strategi pembelajarannya secara tepat.

2. Keaktifan siswa dalam mengikuti pelajaran meningkat karena guru memilih dan menciptakan metode secara kreatif dan inovatif sehingga tidak membosankan.

3. Kemampuan, kreativitas dan profesionalitas guru teruji setelah melakukan kegiatan perbaikan pembelajaran dengan hasil yang memuaskan.

4. Kegiatan Eksplorasi pustaka dapat menumbuhkan minat pada siswa dalam membaca dan menulis.

5. Kegiatan pembelajaran yang menyenangkan dapat tercipta.

Berdasarkan kesimpulan tersebut, beberapa hal sebaiknya dilakukan oleh guru dalam meningkatkan kualitas pembelajaran. Antara lain adalah :

1. Menyusun rencana perbaikan pembelajaran yang tepat dan memuat berbagai instrumen pembelajaran yang dapat menunjang keberhasilan pelaksanaan pembelajaran secara maksimal dan memuaskan.

2. Menciptakan model pembelajaran yang menyenangkan dengan menggunakan metode secara kreatif dan inovatif serta dapat meningkatkan keaktifan dan kemampuan siswa untuk mencapai nilai batas ketuntasan dalam kegiatan pembelajarannya.

3. Menggunakan strategi pembelajaran yang terencana yang dapat memotivasi siswa untuk menemukan pengalamannya sendiri.

4. Guru harus dapat bersikap profesional apabila dalam pelaksanaan kegiatan pembelajarannya kurang berhasil dengan melakukan kegiatan perbaikan pembelajaran yang lebih baik.

5. Mengangkat Eksplorasi Pustaka sebagai Mata pelajaran Mulok Sekolah.

\section{UCAPAN TERIMA KASIH}

Dengan penuh rasa hormat, saya ucapkan teimakasih kepada:

1. Kepala Dinas Pendidikan Kabupaten Lombok Tengah yang telah memfasilitasi, mengizinkan penulis untk mengadakan penelitian hingga dapat terlaksana dengan baik.

2. Bapak Pengurus PGRI Kec. Pringgarata dan Ketua Gugus yang telah menfasilitasi dalam seminar hasil penelitian Guru-guru Kecamatan Pringgarata.

3. Bapak Kepala sekolah yang selalu memberi dukungan sejak awal hingga terlaksananya penelitian ini dengan baik.

4. Rekan-rekan guru yang telah memberi dukungan baik secara moral maupun tindakan langsung dalam pelaksanaan penelitian ini.

\section{DAFTAR RUJUKAN}

[1]. Suparno. 2003. Ketrampilan Dasar Menulis. Jakarta : Universitas Terbuka

[2]. Wardani I.G.A.K. 2003. Penelitian Tindakan Kelas. Jakarta : Universitas Terbuka

[3]. Andayani Dkk. 2015. Pemantapan Kemampuan Profesional (Panduan). Jakarta : Universitas Terbuka

[4]. Suprayekti Dkk. 2005. Pembaharuan Pembelajaran di SD. Jakarta : Universtas Terbuka

[5]. Joan Beck. 2003. Meningkatkan Kecerdasan Anak, hal 154155. Jakarta : Delapratasa

[6]. Nur, Moh. 2016. Pemotivasian Siswa untuk Belajar. Surabaya. University Press. Universitas Negeri Surabaya.

[7]. Soedjadi, dkk. 2000. Pedoman Penulisan dan Ujian Skripsi. Surabaya; Unesa Universitas Press.

[8]. Suryosubroto, B. 1997. Proses Belajar Mengajar di Sekolah. Jakarta: PT. Rineksa Cipta.

[9]. Usman, Uzer. 2000. Menjadi Guru Profesional. Bandung: PT. Remaja Rosdakarya.

[10]. Widoko. 2002. Metode Pembelajaran Konsep. Surabaya: Universitas Negeri Surabaya. 